\title{
Cyanogenic Glycosides in Plants
}

\author{
Ilza A. Francisco and Maria Helena Pimenta Pinotti* \\ Department of Biochemistry, State University of Londrina, PO BOX 6001, 86.051-990, Londrina - PR, Brazil
}

\begin{abstract}
The presence of cyanogenic glycosides was determined in 70 plant species from the campus of the State University of Londrina, PR, Brazil, and a further 45 plant species from the Forestry Reserve on the Doralice Farm in Ibiporã, $P R$, Brazil. Of the vegetative species from the State University of Londrina, $7.1 \%$ showed cyanogenic glycosides: Manihot esculenta (Euphorbiaceae), Passiflora edulis (Passifloraceae), Macadamia ternifolia (Proteaceae), Prunus persica (Rosaceae) and Beloperone sp (Acanthaceae).The first four species were considered to be potentially cyanogenic in the field. From the Forestry Reserve on the Doralice Farm, the plant species with cyanogenic glycosides were: Holocalix balanseae (Caesalpinaceae), Nectranda megapotamica (Lauraceae), Trichilia casareti (Meliaceae), Trichilia elegans (Meliaceae) and Rapanea umbellata (Myrsinaceae), making $11.1 \%$ of the total species analyzed. Only Holocalix balanseae was considered to be potentially cyanogenic in the field.
\end{abstract}

Key words: cyanogenic glycosides; cyanogenic plants; cyanogenesis

\section{INTRODUCTION}

Cyanogenesis is the ability of some plants to synthesize cyanogenic glycosides, which when enzymically hydrolyzed, release cyanohydric acid (HCN), known as prussic acid (Harborne, 1972, 1986, 1993). In most cases, hydrolysis is accomplished by the $\beta$-glucosidase, producing sugars and a cyanohydrin that spontaneously decomposes to $\mathrm{HCN}$ and a ketone or aldehyde (Figure 1). The second step can also be catalyzed by the hydroxynitrile lyase, which is widespread in cyanogenic plants (Harborne, 1993; Gruhnert et al, 1994). In the intact plant, the enzyme and the cyanogenic glycoside remain separated, but if the plant tissue is damaged both are put in contact and cyanohydric acid is released (Bell, 1981; Gruhnert et al, 1994). Cyanohydric acid is extremely toxic to a wide spectrum of organisms, due to its ability of linking with metals $(\mathrm{Fe}++, \mathrm{Mn}++$ and $\mathrm{Cu}++$ ) that are functional groups of many enzymes, inhibiting processes like the reduction of oxygen in the cytochrome respiratory chain, electron transport in the photosynthesis, and the activity of enzymes like catalase, oxidase (Cheeke, 1995; McMahon et al, 1995).

There is strong evidence that cyanogenesis is one of the mechanisms that can serve to the plant as a protective device against predators such as the herbivores. The level of cyanogenic glycosides produced is dependent upon the age and variety of the plant, as well as environmental factors (Cooper-Driver \& Swain, 1976; Woodhead \& Bernays, 1977).

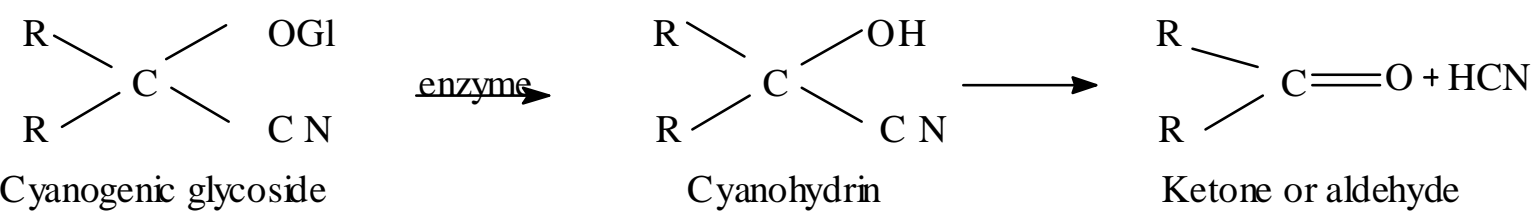

Figure 1 - Pathway of release of HCN by cyanogenic plants.

\footnotetext{
* Author for correspondence
} 
It is usual to find cyanogenic and acyanogenic plants within the same species, where the function of cyanogenesis is revealed through their phenotypic characteristics. Cyanogenesis may not necessarily be used for plant survival; it may take part in metabolic and excretory processes but there certainly is a characteristic of value for these species (Harborne, 1972; Cooper-Driver \& Swain, 1976; Woodhead \& Bernays, 1977; Tokarnia et al, 1994).

Cyanogenic glycosides are widely distributed among 100 families of flowering plants. They are also found in some species of ferns, fungi and bacteria (Harborne, 1972, 1993). There are many economical important plants highly cyanogenic, including white clover, linum, almond, sorghum, the rubber tree and cassava (Tokarnia et al, 1994; Cheeke, 1995).

The aim of this work was to detect cyanogenic glycosides in vegetative species from the Forestry Reserve on the Doralice Farm, Ibiporã, PR, Brazil, and from the campus of the State University of Londrina, Londrina, PR, Brazil.

\section{MATERIAL AND METHODS}

Samples: The plant samples were harvested from March to September in 1996, at two localities: a) a Forestry Reserve on the Doralice Farm in Ibiporã, PR, Brazil (23 $16^{\prime} \mathrm{S}$ and $51^{\circ} 01^{\prime} \mathrm{W}$, altitude $484 \mathrm{~m})$. This farm has a 100 ha spread covered by a continuous forest around which there are areas of cultivation, limited to the east by the Tibagi River and bounded by pieces of ciliar forest (Carmo, 1995); b) the campus of the State University of Londrina in Paraná state that occupies an area of 230 ha east of the city of Londrina (Ornelas, 1991).

Identification of the plants: The plant specimens were processed according to Fidalgo \& Bonomi (1984), and deposited in the Herbarium of the State University of Londrina as reference material. The identification of the plants was performed from published data and comparison with specimens held at the herbarium. Classification of the species was accomplished according to Cronquist (1988).

Detection of cyanogenic glycosides: Cyanogenic glycosides were detected using the technique of the picrate-impregnated paper according to Harbone (1972). The assay was performed in triplicate. Fresh plant material was cut into small pieces and placed in a test tube with $1.5 \mathrm{~mL}$ of distilled water, and 6 drops of chloroform, followed by briefly crushing the material with a glass rod. The tube was stoppered with a cork containing a strip of picrate-impregnated paper hanging down from the stopper, and incubated at ambient temperature for $2 \mathrm{~h}$. A colour change of the paper, from yellow to brown-red, indicated the release of $\mathrm{HCN}$ by the plant. If there was no release of $\mathrm{HCN}$ within $2 \mathrm{~h}$, indicating a negative test, the tube was left at ambient temperature for 24 and $48 \mathrm{~h}$, so that it could be re-examined. A brown-red coloration within $2 \mathrm{~h}$ indicated the presence of cyanogenic glycoside and the respective hydrolytic enzyme, and the plants were considered cyanogenic in the field. A brown-red color appearing within $48 \mathrm{~h}$ indicated that the cyanogenic glycoside spontaneously released HCN without the action of enzyme. No colour change after $48 \mathrm{~h}$ indicated that the test was negative for cyanogenic glycoside.

Picrate paper preparation: Strips of filter paper $(5.0 \times 1.5 \mathrm{~cm})$ were soaked in an aqueous solution of $0.05 \mathrm{M}$ picric acid, previously neutralized with sodium bicarbonate, and filtered. The impregnated paper was left to dry at ambient temperature.

\section{RESULTS AND DISCUSSION}

Forty five plant species were analyzed from the Forestry Reserve on the Doralice Farm. The results are shown in Table 1. 
Table 1 - List of plant species from the Forestry Reserve on the Doralice Farm, Ibiporã, PR, Brazil assayed for the presence of cyanogenic glycosides

\begin{tabular}{|c|c|c|c|}
\hline FAMILY & SPECIES & COMMOM NAME & $\begin{array}{l}\text { VEGETATIVE } \\
\text { PART } \\
\end{array}$ \\
\hline Acanthaceae & Justicia brasiliana & Junta-de-cobra-vermelha & Leaf \\
\hline Alismataceae & Echinodorus grandiflorus & Chapéu-de-couro & Leaf \\
\hline Apocynaceae & Aspidosperma polyneuron & Peroba-rosa & Leaf \\
\hline Bombacaceae & Chorisia speciosa & Paineira & Leaf \\
\hline Caesalpinaceae & Bauhinia forticata & Pata-de-vaca & Leaf \\
\hline Caesalpinaceae & Holocalyx balansae & Alecrim & Leaf \\
\hline Capparidaceae & Capparidastrum $s p$ & & Leaf \\
\hline Cecropiaceae & Cecropia glazioui & Embaúba & Leaf \\
\hline Cecropiaceae & Cecropia pachystachya & Embaúba & Leaf \\
\hline Euphorbiaceae & Croton floribundus & Capixingui & Leaf \\
\hline Fabaceae & Lonchocarpus guilleminianus & Embirá-branca & Leaf \\
\hline Fabaceae & Machaerium hatschbachii & Caviúna & Leaf \\
\hline Lauraceae & Endlicheria paniculata & Canela-de-frade & Leaf \\
\hline Lauraceae & Nectandra megapotamica & Canela-preta & Leaf \\
\hline Lauraceae & Ocotea indecora & Canela & Fruit \\
\hline Malvaceae & Bastardiopsis densiflora & & Peduncle \\
\hline Melastomataceae & Miconia discolor & Pixirica & Leaf \\
\hline Meliaceae & Cabralea canjerana & Canjerana, canjaran & Fruit \\
\hline Meliaceae & Guarea kunthiana & Figo-do-mato & Fruit/seed/leaf \\
\hline Meliaceae & Guarea macrophylla & Ataúba & Fruit \\
\hline Meliaceae & Trichia casaretti & Catiguá-vermelho & Fruit \\
\hline Meliaceae & Trichilia catigua & Catiguá & Leaf \\
\hline Meliaceae & Trichilia elegans & Pau-ervilha & Leaf \\
\hline Meliaceae & Trichilia pallida & Baga-de-morcego & Leaf \\
\hline Mimosaceae & Acacia polyphylla & Monjoleiro & Leaf \\
\hline Mimosaceae & Anadenanthera colubrina & Angico & Leaf \\
\hline Mimosaceae & Inga marginata & Ingá-mirim & Leaf \\
\hline Mimosaceae & Inga striata & Ingá-banana & Leaf \\
\hline Mimosaceae & Piptadenia gonoacantha & Pau-jacaré & Leaf \\
\hline Moraceae & Ficus guaranitica & Figo-do-mato & Fruit \\
\hline Moraceae & Sorocea bomplandi & Falsa espinheira-santa & Leaf \\
\hline Myrsinaceae & Rapanea umbellata & Capororoca & Leaf \\
\hline Nyctaginaceae & Bougainvillea spectabilis & Primavera & Leaf \\
\hline Nyctaginaceae & Pisonia aculeata & Pega-pinto & Fruit \\
\hline Phytolaccaceae & Galesia intergrifolia & Pau-d'alho & Leaf \\
\hline Piperaceae & Piper sp & & Leaf \\
\hline Rubiaceae & Palicourea sp & & Leaf \\
\hline Rutaceae & $\begin{array}{l}\text { Baufourodendron } \\
\text { Riedelianum }\end{array}$ & Pau-marfin & Leaf \\
\hline Rutaceae & Pilocarpus pennatifolius & Cutia-branca, jaborandi & Leaf \\
\hline Rutaceae & Zanthoxylum riedelianum & Mamica-de-porca & Leaf \\
\hline Sapotaceae & Crysophyllum gonocarpum & Guatambú-de-leite & Leaf \\
\hline Simaroubaceae & Picramnia ramiflora & Cedrilho, cedrinho & Leaf \\
\hline Verbenaceae & Aegiphila $s p$ & & Leaf \\
\hline Verbenaceae & Vitex megapotamica & Tarumã & Leaf \\
\hline Violaceae & Hybanthus biggibosus & & Leaf \\
\hline
\end{tabular}

Of the species examined only Holocalix balanseae (Caesaepinaseae) released HCN within $2 \mathrm{~h}$, showing that this plant species has cyanogenic glycoside and the specific enzyme for its hydrolysis. The plants, Nectandra megapotamica (Lauraceae), Trichilia casareti and Trichilia elegans (Meliaceae), released HCN slowly, within $24 \mathrm{~h}$, while Rapanea umbellata (Myrsinaceae) released cyanide after $24 \mathrm{~h}$. The HCN of the cyanogenic glycoside in these cases was not released enzymatically. 
Table 2 - List of plant species from the Campus of the State University of Londrina, Londrina, PR, Brazil, assayed for the presence of cyanogenic glycosides

\begin{tabular}{|c|c|c|c|}
\hline FAMILY & SPECIES & COMMON NAME & VEGETATIVE PART \\
\hline Acanthaceae & Beloperone $s p$ & Camarãozinho-de-jardim & Flower \\
\hline Agavaceae & Agave sp & Lírio-de-nossa senhora & Leaf \\
\hline Agavaceae & Cordyline $s p$ & Cordiline & Flower \\
\hline Agavaceae & Sancevieria $s p$ & Espada-de-são jorge & Leaf \\
\hline Agavaceae & Yucca aloefolia & Vela-da-pureza & Leaf \\
\hline Anacardiaceae & Mangifera indica & Mangueira & Fruit/inflorescence \\
\hline Annonaceae & Annona cearensis & Fruta-do-conde & Fruit \\
\hline Apocynaceae & Plumeria rubra & & Flower/Stalk \\
\hline Araucariaceae & Araucaria angustifolia & Pinheiro-do-Paraná & Fruit \\
\hline Asclepiadaceae & Asclepia curassavica & & Flower \\
\hline Asteraceae & Bidens pilosa & Picão & Leaf \\
\hline Asteraceae & Eupatorium maximilianii & & Flower \\
\hline Asteraceae & Taraxacum officinale & Dente-de-leão & Flower \\
\hline Asteraceae & Vernonia polyanthes & & Flower \\
\hline Asteraceae & Wedellia paludosa & & Flower \\
\hline Bignoniaceae & Jacaranda micrantha & Caroba & Fruit \\
\hline Bignoniaceae & Tabebuia chrysotricha & Ipê-amarelo & Flower \\
\hline Bignoniaceae & Tabebuia heptaphylla & Ipê-roxo & Fruit \\
\hline Bignoniaceae & Tabebuia roseo-alba & Ipê-branco & Fruit \\
\hline Bixaceae & Bicha olerana & Urucum & Flower \\
\hline Bombacaceae & Chorisia speciosa & Paineira & Fruit \\
\hline Caesalpinaceae & Bauhinia forticata & Pata-de-vaca & Seed \\
\hline Caesalpinaceae & Caesalpinia peltophoroides & Sibipiruna & Flower \\
\hline Caesalpinaceae & Cassia grandis & Canafístula & Leaf \\
\hline Caesalpinaceae & Delonix regia & Falmboyant & Fruit \\
\hline Cecropiaceae & Cecropia adenopus & Embaúba & Leaf \\
\hline Chrysobalanceae & Correpia grandiflora & Oiticica & Leaf \\
\hline Commelinaceae & Zebrina sp & Zebrinha & Leaf \\
\hline Convolvulaceae & Catharantus roseus & Boa-noite & Flower \\
\hline Convolvulaceae & Ipomea geramoelit & Bom-dia & Flower \\
\hline Crassulaceae & Bryophyllum $s p$ & Folha-da-fortuna & Leaf \\
\hline Ericaceae & Rhododendron indicum & Azaléia & Flower \\
\hline Euphorbiaceae & Euphorbia heterophylla & Leiteiro & Leaf \\
\hline Euphorbiaceae & Euphorbia tirucalli & Coroa-de-cristo & Leaf \\
\hline Euphorbiaceae & Manihot esculenta & Mandioca, cassava & Leaf \\
\hline Euphorbiaceae & Ricinus comunis & Mamona & Seed \\
\hline Fabaceae & Cajanus cajanus & Feijão-andu & Seed \\
\hline Fabaceae & Erythrina speciosa & Eritrina, suinã & Flower \\
\hline Fabaceae & Leucena glauca & & Leaf \\
\hline Fabaceae & Machaerium stiptatum & & Leaf \\
\hline Fabaceae & Phaseolus vulgaris & Feijão & Fruit \\
\hline Geraniaceae & Geranium $s p$ & Gerânio & Flower \\
\hline Lamiaceae & Melissa offinalis & Erva cidreira & Leaf \\
\hline Lamiaceae & Origanum majorana & Orégano & Leaf \\
\hline Lauraceae & Persea gratissima & Abacateiro & Fruit \\
\hline Liliaceae & Aloe vera & Babosa & Leaf \\
\hline Liliaceae & Lilium $s p$ & Lírio & Bulb \\
\hline Malvaceae & Hibiscus rosa sinensis & Hibisco & Flower \\
\hline Melastomataceae & Tibouchina granulosa & Quaresmeira & Flower \\
\hline Meliaceae & Cedrela fissilis & Cedro & Fruit \\
\hline Meliaceae & Melia azedarach & Santa-bárbara & Seed/leaf/fruit \\
\hline Mimosaceae & Calliandra selloi & Esponjinha,cabelo-de-anjo & Leaf \\
\hline Moraceae & Artocarpus incisa & Fruta-pão & Fruit \\
\hline Moraceae & Ficus auriculata & Figo-bravo & Fruit \\
\hline Moraceae & Ficus elastica & Seringueira-falsa & Leaf \\
\hline Myrtaceae & Psidium guajava & Goiabeira & Leaf \\
\hline Nyctaginaceae & Bougainvillea spectabilis & Primavera & Flower \\
\hline Oleaceae & Jasminum $s p$ & Jasmin & Flower \\
\hline Passifloraceae & Passiflora edulis & Maracujá & Floral button/leaf \\
\hline Plantaginaceae & Plantago major & Tansagem & Leaf \\
\hline
\end{tabular}


Table 2 - (cont.) List of plant species from the Campus of the State University of Londrina, Londrina, PR, Brazil, assayed for the presence of cyanogenic glycosides

\begin{tabular}{llll}
\hline \multicolumn{1}{c}{ FAMILY } & \multicolumn{1}{c}{ SPECIES } & \multicolumn{1}{c}{ COMMON NAME } & \multicolumn{1}{c}{ VEGETATIVE PART } \\
\hline Poaceae & Brachiaria sp & Leaf \\
Proteaceae & Grevillea robusta & Grevilia & Stem \\
Proteaceae & Macadamia ternifolia & Noz, macadamia & Leaf/flower \\
Rosaceae & Prunus persica & Pessegueiro & Flower/leaf \\
Rubiaceae & Coffea arabica & Café & Leaf \\
Rutaceae & Citrus sinensi & Laranjeira & Leaf/flower \\
Tiliaceae & Corchorus capsularis & & Leaf \\
Tropaeolaceae & Tropaeolum brasilienses & Capuchinha & Flower \\
Urticaceae & Boehmeria caudata & Assa-peixe & Leaf \\
Verbenaceae & Lantana camara & & Flower \\
& & & \\
\hline
\end{tabular}

Cyanogenesis could be revealed comparing plants through their phenotypic characteristics. As confirmed by Harborne (1972, 1992), chemical polymorphism in clover was derived by geneticists through breeding experiments, which showed that two genes were responsible for cyanogenesis: Ac, controlling the synthesis of cyanogenic glycoside, and $\mathrm{Li}$ that controls the synthesis of the enzyme necessary for its breakdown. Four genotypes (Ac $\mathrm{Li}, \mathrm{Ac} \mathrm{Li}, \mathrm{Ac} \mathrm{Li}$ and ac li) in natural populations were identified phenotypically by the chemical test employing picrate paper. Only type Ac Li was registered as cyanogenic in the field.

Following analyses it was concluded that of the 45 species of the Forestry Reserve examined, only $11,1 \%$ released $\mathrm{HCN}$, and could be described as producers of cyanogenic glycoside. Only one plant species (Holocalix balansae) could released cyanide within $2 \mathrm{~h}$, and can be considered cyanogenic in the field.

Seventy one plant species from the campus of the State University of Londrina were analysed. The results are shown in Table 2.

Of the 70 species examined, $7.1 \%$ released HCN within $2 \mathrm{~h}$, and were considered cyanogenic in the field. They included Manihot esculenta (Euphorbiaceae), Passiflora edulis (Passifloraceae), Macadamia ternifolia (Proteaceae) and Prunus persica (Rosaceae). Beleperone sp (Acanthaceae) released $\mathrm{HCN}$ within $24 \mathrm{~h}$; although it was cyanogenic it is not cyanogenic in the field because the evolution of $\mathrm{HCN}$ is very slow; most likely non-enzymic.

In general, wild plant species are more resistant to predators due to the presence of toxic factors acting as defense mechanism against them. Sotelo et al (1995), comparing the chemical composition of cultivated and wild beans (Phaseolus vulgaris), showed that although the cultivated beans had better profiles of amino acids than the wild beans, the content of anti-nutritional factors was less. At the campus of University of Londrina, the percentage of plants having cyanogenic glycosides was lower $(7.1 \%)$ than those examined from the Forestry Reserve at the Doralice Farm (11.1\%), but four species were cyanogenic in the field against one species from the Forestry Reserve.

The plants cultivated in the university campus were mainly exotic introduced species, coming from places totally different from which they were introduced, and certainly suffered evolutionary pressure before their adaptation to the new habitat. By comparison, plants in the Forestry Reserve were native species having evolved together with same adaptative conditions in specific ecosystem. The plant species containing cyanogenic glycosides in the University campus, and those in the Forestry Reserve were different, with both sources having suffered diverse types of predation. It was, however, difficult to reach some conclusion with respect to these differences.

The importance of this work relied at the large number of plant species that were analysed. The study could serve as reference to new studies about cyanogenic glycosides in these plants.

\section{ACKNOWLEDGMENTS}

The authors gratefully acknowledge State University of Londrina for the financial support, Doralice Farm for the botanical material, and Dr. Robert F.H. Dekker of Tecnologia de Alimentos e Medicamentos, UEL, for revising the English and helpful comments. 


\section{RESUMO}

A presença de glicosídeos cianogênicos foi testada em 70 espécies de plantas do Campus da Universidade Estadual de Londrina, PR, Brasil e em 45 espécies de plantas do Remanescente Florestal da Fazenda Doralice, Ibiporã, PR, Brasil. Das espécies vegetais da Universidade Estadual de Londrina, 7,1\% apresentaram glicosídeos cianogênicos: Manihot esculenta (Euphorbiaceae), Passiflora edulis (Passifloraceae), Macadamia ternifolia (Proteaceae), Prunus persica (Rosaceae) e Beloperone $s p$ (Acanthaceae). As primeiras quatro espécies foram consideradas potencialmente cianogênicas no campo. Do Remanescente Florestal da Fazenda Doralice, as espécies vegetais com glicosídeos cianogênicos foram: Holocalix balanseae (Caesalpinaceae), Nectandra megapotamica (Lauraceae), Trichilia casareti (Meliaceae), Trichilia elegans (Meliaceae) e Rapanea umbellata (Myrsinaceae), perfazendo $11,1 \%$ das espécies totais analisadas. Somente Holocalix balanseae foi considerada ser potencialmente cianogênica no campo.

\section{REFERENCES}

Bell, E. A. (1981), The biochemistry of plant. Academic Press, New York

Carmo, M.R.B. (1995) Levantamento florístico e fitossociológico do Remanescente Florestal da Fazenda Doralice, Ibiporã-Pr., Londrina: UEL, Monography, Universidade Estadual de Londrina, Londrina, PR, Brasil

Cheeke, P.R. (1995), Endogenous toxins and mycotoxin in forage grasses and their effects on livestock. J. Ani. Sci., 73, 909-918
Cooper-Driver, G.A.; Swain, T. (1976), Cyanogenic polymorphism in bracken in relation to herbivore predation. Nature, 260, 604

Cronquist, A. (1988), The evolution and classification offlowering plants. New York: Botanical Garden

Fidalgo, O.; Bononi, V.L.R. (1984), Técnicas de coleta, preservação e herborização de material botânico. São Paulo: Botanical Institute, (nº 4), 62

Gruhnert, C.; Biehl, B.; Selmar, D. (1994), Compartmentation of cyanogenic glucosides and their degrading enzymes. Planta, 195, 36-42

Harborne, J.B. (1972), Cyanogenic glucosides and their function. In: Phytochemical ecology. Academic Press, London, 104-123

Harborne, J.B (1986), Recent Advances in Chemical Ecology. Nat. Prod. Rep., 324-344

Harborne, J.B. (1993), Plant toxins and their effects on animals. In: Introduction to Ecological Biochemistry. Academic Press, London, 71-103

McMahon, J.M.; White, W.L.B.; Sayre, R.T. (1995) Cyanogenesis in cassava (Manihot esculenta Crantz).J. Exp. Bot., 46, 731-741

Ornelas, M.E. (1991), Degradação ambiental em áreas de preservação. Parque Arthur Thomas, Londrina, PR, Londrina. Monography Universidade Estadual de Londrina, Londrina, PR, Brasil

Sotelo, A.; Sousa, H.; Sanches, M. (1995), Comparative study of the chemical composition of wild and cultivated beans (Phaseolus vulgaris). Plant Foods for Human Nutrition, 47, 93-100

Tokarnia, C.H.; Peixoto, P.V.; Dobereiner, J. (1994), Intoxicação experimental por Piptadenia macrocarpa (Leg. Mimosoideae) em bovinos. Pesq. Vet. Bras., 14, 57-63

Woodhead, S.; Bernays, E. (1977), Change in release rates of cyanide in relation to patability of Sorghum to insects. Nature, 270 235- 236

Received: July 07, 1999; Revised: December 12, 1999 Accepted: March 20, 2000. 